\title{
Interactive Multimedia to Improve Mathematics Learning Outcomes in Elementary School Students
}

\author{
Tuti Susanti ${ }^{1}$, Ine Kusuma Aryani ${ }^{2}$ \\ \{ tutisusanti078@gmail.com¹, inepascapendas@gmail.com² $\}$ \\ Magister Pendidikan Dasar, Universitas Muhammadiyah Purwokerto, J1 KH Ahmad \\ Dahlan, Banyumas 53182, Indonesia
}

\begin{abstract}
This study aims to determine the use of interactive multimedia to improve mathematics learning outcomes of elementary school students. Interactive multimedia is an integration of several media in audio, visual, and animation using hardware and software. The type of data used is secondary data. The method used in this research is the literature study method. Data obtained through literature search in the form of research articles, which are then collected, analyzed, and concluded to get conclusions about literature study. Based on the results of literature studies from several research results and journal articles show that interactive multimedia can improve mathematics learning outcomes for elementary school students.
\end{abstract}

Keywords: interactive multimedia, mathematics learning outcomes, elementary school

\section{Introduction}

Since the beginning of the 4.0 industrial revolution era, technology has developed so rapidly and dynamically. This has an impact on all sectors, one of which is education. This condition certainly affects students' current learning behavior, namely utilizing technological devices for the learning process. The development of information technology and computer networks has changed the patterns and methods of learning in individuals [1]. Learning activities that are happening now are more likely to be flexible than what happened before. The learning and teaching process is no longer an event that depends on time and space factors.

In the learning process, teachers can use technological devices to deliver learning material to students, one of which is using a cellphone or smartphone. Learning through cell phones or mobile learning (m-learning) has become part of an educational process that is overgrowing along with the development of technology itself. The advantage of using $\mathrm{m}$ learning in teaching and learning is that it can help students improve literacy and numeracy skills [2]. In simple terms, numeracy can be defined as applying the concept of numbers and arithmetic operations skills in everyday life (for example at home, work, and participation in community life and as citizens). The idea of numbers and arithmetic operations is a material contained in Mathematics.

Mathematics is a subject that is often applied in everyday life. Therefore mathematics is one of the main subjects in the applicable education curriculum in Indonesia. Mathematics is one of the main subjects taught not only in elementary schools but at every level of education which, aims to develop students' thinking skills [3]. Mathematics introduces concepts, thinking skills, and strategies that are essential in everyday life. Learning mathematics stimulates curiosity, encourages creativity, and equips students with skills needed in life outside of school. 
Learning mathematics in elementary school is one of the studies that is always interesting to put forward because of the differences in characteristics, especially between the nature of children and the nature of mathematics. Elementary school-age children are experiencing development in their level of thinking. The thinking stage of elementary school children is not yet formal, especially for low-grade students, some of whom are still at the concrete pre-operational stage. On the other hand, mathematics is a deductive, traditional, hierarchical and abstract science. Given the differences in these characteristics, special abilities from the teacher are needed to bridge the two things. The study of current content knowledge and pedagogical content knowledge has been specialized in mathematics [4]. This specificity is due to the complexity of knowledge that teachers need to have when teaching mathematics. One way that can be used is by delivering learning material through learning media. so that the teacher must know the appropriate learning media to use in providing learning material, especially mathematics.

Media in the learning process is an intermediary or introduction to message sources by receiving messages, stimulating thoughts, feelings, attention and willingness so that they are encouraged and involved in learning [5]. The physical equipment in question includes original objects, printed materials, visuals, audio, audiovisuals, multimedia, and the web. The development of learning media is currently carried out by considering technological advances and current trends in student learning behavior, namely, students using technological devices for the learning process, for example cellular phones or smartphones. One of the learning media that can be developed in the current condition is interactive multimedia. Multimedia combines of text, graphics, moving image audio (video and animation that allows users to navigate, interact, create and communicate [6].

Mobile learning by utilizing cellular phones, indeed provides many benefits to students. This was also expressed by [1], that multimedia programs are a product of advances in digital technology that are currently developing. The multimedia program that is used as teaching material in learning activities is able to provide rich learning experiences for its users.

Interactive multimedia is one type of multimedia that has a tool that is used to control and can be used by the end-user concerned so that the end-user can choose his destination [7]. The characteristics of multimedia interactive learning media, namely: (1) having more than one convergent media, for example, combining audio and visual elements, (2) being interactive, in the sense of having the ability to accommodate user responses, and (3) being independent, in Understanding provides convenience and completeness of content in such a way that users can use it without the guidance of others. Based on these definitions and characteristics, interactive multimedia can be used in learning and is expected to have a positive impact on student learning outcomes.

Learning outcomes are an indicator of the transition that grows in students after implementing a learning method using an assessment tool that has been established by the school by the teacher [8]. Learning outcomes cannot be separated from all learning activities in 3 aspects, namely: (1) good teaching in class; (2) school infrastructure; (3) or situations outside of school. So it can be concluded that learning outcomes is obtained from the abilities, skills, and knowledge developed by the subjects; and work individually or in groups. There are three aspects in learning outcomes, namely: (1) cognitive; (2) psychomotor; (3) affective. Referring to the research findings been carried out, the researcher uses aspects of student test results (cognitive aspects) for the written assessment of student learning outcomes.

Based on the description above, there is a need for literature review research to discuss interactive multimedia in mathematics learning in elementary schools [3]. This is because of the demand for learning media that can convey abstract mathematics learning material to students 
who are still in the stage of concrete operational cognitive development. Furthermore, the study of interactive multimedia will be associated with the acquisition of student learning outcomes in mathematics learning, in this case the results learning in the cognitive realm. Given the importance of the above study, the authors initiated a literature review study entitled Interactive Multimedia to Improve Primary School Student Mathematics Learning Outcomes. So the formulation of the problem in this study is How interactive multimedia can improve the mathematics learning outcomes of elementary school students? As for the purpose of this study is to examine the literature on learning outcomes of elementary school students using interactive multimedia in mathematics learning. So it is expected to see an increase in student learning outcomes through the use of interactive multimedia in the mathematics learning process in elementary schools.

\section{Research Methodology}

This literature study is carried out by identifying, assessing, evaluating and interpreting the research that is available. By using this method, a systematic review and identi cation of journals can be carried out, which in each process follows the steps or protocols that have been established [9]. The criteria for scientific articles used as data are in the form of scientific articles sourced from journals and proceedings with the latest 10 years, namely from 2011-2020. Scientific article data used is a minimum of 10 articles. The steps taken in selecting articles as data in this study are as follows: (1) Visit the following web https://scholar.google.co.id; (2) The next step is to enter search keywords, namely interactive multimedia, mathematics learning, elementary school. Based on the search results, it was obtained that the number of articles according to keywords via the web https://scholar.google.co.id was 34 articles and; (3) The next step is validating scientific articles by eliminating scientific articles that are not following the ideas and objectives of the research. Scientific articles are also selected by year. The scientific article data obtained in this process is as many as ten articles. (4) The next stage is that the researcher classifies articles on interactive multimedia related to learning mathematics. The metadata for the articles is tabulated in a table which includes the author's name, the year published, the name of the journal, and the research results. After that, the researcher reviewed and analyzed the article in depth, especially regarding the research results presented in the discussion and conclusion sections. At the end of the study, the researcher compared the findings presented in the article and gave conclusions [10].

\section{Result and Discussion}

Based on the results of the identification, screening, and filtering processes, there were ten articles that were relevant to the research objectives. This article focuses on developing interactive multimedia to improve mathematics learning outcomes for elementary school students. The analysis of 10 reports is shown in table 1 . 
Table 1: Results of Research on the Use of Multimedia in Mathematics Learning in Elementary Schools

\begin{tabular}{ll}
\hline Researcher and Year & Journal \\
\hline (Mila C Paseleng dan & Scholaria: Jurnal \\
Rizki Afiryani, 2015) & Pendidikan Dan \\
& Kebudayaan
\end{tabular}

Research result

Based on the pre-test value data in the control and experimental classes, Namely 51.31 and 50.44 , which means that the two categories have almost the same initial ability, after being given treatment by giving post-test, a significant difference in value is obtained, namely the control class is 77.06 with a difference of 25, 75 and the experimental class was 87.56 with a difference of 38.37 . 108. Based on the pretest and posttest value data, the normalized gain $(G)$ value of the experimental class was 0.780037 in the high category, while the control class was 0.528856 with the moderate category. This shows that the increase in learning outcomes in the experimental class is higher than the control class.

(Nur Hidayati, 2017) Jurnal Pendidikan Ke-SD-an

Based on the results of research and discussion, it can be concluded that learning using interactive multimedia is more effective than conventional learning on Distance and Speed material on the mathematics learning outcomes of fifth-grade students of SDN Jurug Sewon. This was evidenced by the mean test results for the experimental class (78.67), which higher than the mean for the control class (56.48). In addition, the number of students who completed the experimental group was more than the control group.

(Gusti Ngurah Satria Nugraha, I Made

Jurnal EDUTECH

Tegeh, I Komang

Sudarma, 2019)

(Margarita, N, 2018)

Universitas
Pendidikan Ganesha

Based on the data on the pre-test and post-test scores of these 30 students, a t-test was carried out for a correlated sample. The mean score of the students' pretest was 56.00 and the average posttest score of the students was 88.00. on Mathematics learning outcomes before and after using Interactive Learning Multimedia oriented to Local Wisdom in class III students of the 2018/2019 Academic Year at SD Negeri 1 Paket Agung.

$\begin{array}{ll}\text { Journal for Lesson } & \text { The results of this study indicate that the } 2 \text { SD } \\ \text { and Learning Studies that did not use the media resulted in an }\end{array}$ average pretest score of 72.56 and posttest 80.12 and sig. (2- tailed) 0.004. Furthermore, at 2 elementary schools using the media, the average pretest was 75.74 and posttest was 83.62 and sig. (2-tailed) 0.000 . So it can be concluded that interactive multimedia can improve student learning outcomes. 


\begin{tabular}{ll}
\hline (Sari, I. P., Nurtamam, & Jurnal Pendidikan \\
M. E., \& Hanik, U. & dan Pembelajaran \\
2020) & Sekolah Dasar
\end{tabular}

(Mutrikoh, M., Marzuki, M., \& Sabri, dan Pembelajaran T., 2020)

(Tanjung, S. 2019).

JURNAL

TEKNOLOGI

INFORMASI \& KOMUNIKASI

DALAM PENDIDIKAN

(Fauziyyah, F. N., \& Juhri, J., 2017)

Primary: Jurnal

Keilmuan dan

Kependidikan Dasar

(Fredy, F., \& Soenarto, Jurnal Prima

S. 2013) Edukasia
In this study, the learning outcomes test was conducted twice, namely in the media trial, students, obtained an average score of 88.88 with a learning completeness of $100 \%$. And in the second test results of learning in the use trial got an average score of 93.67 students with learning completeness of $100 \%$. This shows that interactive multimedia can improve student learning outcomes.

Based on the knowledge value data, it was obtained that the average value of students' knowledge was 79.79 , which fulfilled the effective criteria for learning knowledge of squares and triangles. Based on the data, 22 students completed classically with the percentage of completeness reaching $91 \%$. Based on the skill value data, it was obtained that the average score of students was 83.67, which met the practical criteria for learning rectangular and triangular skills. Based on the data, 24 students completed classically, namely with a percentage of completeness reaching $100 \%$.

At the distribution stage in four different schools, there was an average increase in the pretest and posttest scores, from 63.65 to 86.9. As well as the average percentage of the results of the assessment of culture-based interactive multimedia products got a value of $83.56 \%$ with excellent criteria. So it can be outcome that the product of research development of culture-based interactive learning media in mathematics is very effective.

Based on the results of the practice tests for achieving the learning objectives carried out after the use of cheerful interactive multimedia shows a percentage of $84.38 \%$ is classified as good because the average results reach the predetermined KKM value. That means, that the use of interactive multimedia is fun to be used in the Mathematics subject of the Elements and Nature of Flattering in class II SD / MI.

The t-test results show that the t-count score is greater than the t-table $(4.034>2.01)$, and the n-gain test results show that the increase in student learning outcomes in the experimental class is higher than the control class $(0.57>0.42)$, so that It can be concluded that learning using multimedia is more effective than learning using PowerPoint 


\begin{tabular}{lll}
\hline (Hermawan, H. 2016) & $\begin{array}{l}\text { media in improving student learning } \\
\text { outcomes. } \\
\text { Publikasi Ilmiah } \\
\text { Universitas } \\
\text { Muhammadiyah } \\
\text { Surakarta. }\end{array}$ & $\begin{array}{l}\text { The average final score of students for test } \\
\text { result I was } 77.80 \text { and completed } 100 \% \text {. The } \\
\text { average final score of students for the second } \\
\text { result test was } 80.82 \text { and } 100 \% \text { complete. The } \\
\text { results of Observations of student activities in } \\
\text { learning showed a score of 3.32 and were in a } \\
\text { excellent category. So, these results have met } \\
\text { the indicators of the effectiveness of learning } \\
\text { media, namely the learning media developed } \\
\text { is said to be effective if (1) the average final } \\
\text { score of the students' mathematics learning } \\
\text { outcomes test at each stage is at least in the } \\
\text { school KKM which is } 72 \text { and (2) The average } \\
\text { score of student activity is at least in the } \\
\text { excellent category (2.50 < Ra <3.50), so the } \\
\text { learning media developed can be said to be } \\
\text { effective }\end{array}$ \\
\hline
\end{tabular}

Based on table 1, there are research articles from Paseleng and Arfiyani getting the results that interactive multimedia can improve student learning outcomes [3], this can be seen from the increase in learning outcomes in the experimental class with an average result value of 87.56 , higher than the mean value of the control class results, namely 77.06 . Then, research by Hidayati found that learning using interactive multimedia was more effective than conventional learning on Distance and Speed on the mathematics learning outcomes of fifth-grade students of SDN Jurug Sewon [11]. This is evidenced by the mean test result of the experimental class, which is 78.67, which is higher than the mean of the control class, which is 56.48. Further research by Nugraha et al.[12], obtained the result that there was an increase in student learning outcomes as indicated by the average acquisition of students' pretest scores was 56.00 and the average posttest score of students was 88.00. on the results of learning mathematics before and after using Interactive Learning Multimedia oriented to Local Wisdom in class III students of the 2018/2019 academic year at SD Negeri 1 Paket Agung.

The results of the research conducted Margarita [13], showed that the 2 SD that did not use the media resulted in an average pretest score of 72.56 and posttest 80.12 . Furthermore, at two elementary schools using the media, the average pretest was 75.74 and, posttest was 83.62. So it can be concluded that interactive multi-media can improve student learning outcomes. Furthermore, research conducted by Sari et al. in this study carried out the test of learning outcomes twice, namely in media trials, students obtained an average score of 88.88 with learning completeness of $100 \%$ [14]. And in the second test results of learning in the use trial got an average score of 93.67 students with learning completeness of $100 \%$. This shows that interactive multimedia can improve student learning outcomes. Subsequent research was carried out [15], it was found that the value of knowledge obtained by the average value of students' knowledge was 79.79, it have shown the effective criteria for learning knowledge of squares and triangles. Based on the data, 22 students completed classically with the percentage of completeness reaching $91 \%$. Based on the skill value data, it was obtained that the average score of students was 83.67, which met the effective criteria for learning rectangular and triangular skills. Based on the data, 24 students completed classically, namely with a percentage of completeness reaching $100 \%$. 
Subsequent research conducted by Tanjung showed that the distribution stage in four different schools showed an increase in the average pretest and posttest scores, from 63.65 to 86.9 , so it can be concluded that the use of interactive multimedia can improve student learning outcomes [16]. Thus, Fauziyyah and Juhri reported the achievement of learning objectives after the use of cheerful interactive multimedia showed a percentage of $84.38 \%$, so it can be concluded that interactive multimedia is effectively used in learning because learning outcomes can reach the predetermined Learning Mastery [17].

Furthermore, the research conducted by Fredy and Sunarto[18] concluded that learning using multimedia is more effective than learning using PowerPoint media in improving student learning outcomes. Besides, the research conducted by Hermawan showed increase in student learning outcomes in the use of interactive multimedia in mathematics learning. [19]. The average final score of students for the first test was 77.80 and $100 \%$ complete The intermediate final score of students for the second result test was 80.82 and $100 \%$ complete.

Learning outcomes are an indicator of the transition that grows in students after implementing a learning method using an assessment tool that has been established by the school by the teacher [8]. Learning outcomes cannot be separated from all learning activities in 3 aspects, namely: (1) good teaching in class; (2) school infrastructure; (3) or situations outside of school. So it can be concluded that learning outcomes is obtained from the abilities, skills, and knowledge developed by the subjects; and work individually or in groups.

Demand for learning media that can convey abstract mathematics learning material to students who are still in the stage of concrete operational cognitive development [20]. Furthermore, the study of interactive multimedia will be associated with the acquisition of student learning outcomes in mathematics learning, in this case the results learning in the cognitive realm [21].

\section{Conclusions}

Based on the results of the literature review analysis research, it can be concluded that interactive multimedia can improve student learning outcomes in mathematics learning in elementary schools.

\section{Acknowledgements}

The author would like to thank the Muhammadiyah University of Purwokerto for providing the opportunity for researchers to conduct research.

\section{References}

[1] Benny A, dkk (2019). Pengembangan Bahan Ajar (Edisi 2). Universitas Terbuka.

[2] Bujeng B, Kamis A, Hussain MA, Rahim MB, Soenarto S. Validity and reliability of multimedia interactive making clothes (mimp) module for home science subjects. International Journal of Innovative Technology and Exploring Engineering. 2019;8(8):593-6.

[3] Paseleng MC, Arfiyani R. Pengimplementasian media pembelajaran berbasis multimedia interaktif pada mata pelajaran matematika di sekolah dasar. Scholaria: Jurnal Pendidikan Dan Kebudayaan. 2015 Dec 8;5(2):131-49.

[4] Novikasari I. Factors Affecting the Development of Mathematical Knowledge for Teaching and Mathematical Beliefs of Prospective Primary Teachers. International Electronic Journal of Mathematics Education. 2017 May 29;12(3):243-64.

[5] Abi Hamid M, Ramadhani R, Masrul M, Juliana J, Safitri M, Munsarif M, Jamaludin J, Simarmata J. Media pembelajaran. Yayasan Kita Menulis; 2020 Jul 29.

[6] Darmawan, D. Teknologi Pembelajaran. PT Remaja Rosdakarya. 2011.

[7] Asmoro SW and Pramono J. Desain Media Interaktif. ANDI Yogyakarta. 2019. 
[8] Soemantri N. Menggagas Pembaharuan Pendidikan IPS. Bandung: PT. Remaja Rosdakarya. 2001.

[9] Triandini E, Jayanatha S, Indrawan A, Putra GW, Iswara B. Metode Systematic Literature Review untuk Identifikasi Platform dan Metode Pengembangan Sistem Informasi di Indonesia. Indonesian Journal of Information Systems. 2019 Feb 23;1(2):63-77.

[10] Sartika S, Octafianti M. Pemanfaatan Kahoot Untuk Pembelajaran Matematika Siswa Kelas X Pada Materi Sistem Persamaan Linear Dua Variabel. Journal On Education. 2019 Apr 15;1(3):373-85.

[11] Hidayati N. Efektivitas pembelajaran menggunakan multimedia interaktif (adobe flash CS6) terhadap hasil belajar matematika siswa kelas V SD N Jurug Sewon. Trihayu: Jurnal Pendidikan KeSD-an. 2017;3(3).

[12] Nugraha GN, Tegeh IM, Sudarma IK. Pengembangan Multimedia INteraktif Matematika Berorientasi Kearifan Lokal Kelas 3 Sekolah dasar negeri 1 Paket Agung. Jurnal Edutech Undiksha. 2019 Aug 7;7(1):12-22.

[13] Margarita N. Pengembangan Multimedia Interaktif Sebagai Alat Bantu Pembelajaran Dengan Model PBL Untuk Peningkatan Hasil Belajar Matematika. Journal for Lesson and Learning Studies. 2018 Aug 1;1(3):243-57.

[14] Sari IP, Nurtamam ME, Hanik U. Pengembangan Multimedia Interaktif Berbasis Game 2D Flash Pada Pembelajaran Matematika Materi Pecahan Sederhana Untuk Siswa Kelas III UPTD SDN Banyuajuh 4 Kamal. Widyagogik: Jurnal Pendidikan dan Pembelajaran Sekolah Dasar. 2020 May 7;7(2):83-91.

[15] Mutrikoh M, Marzuki M, Sabri T. PENGEMBANGAN MULTIMEDIA POWER POINT BERBASIS ISPRING 8 PADA PEMBELAJARAN MATEMATIKA DI SEKOLAH DASAR. Jurnal Pendidikan dan Pembelajaran Khatulistiwa.;9(4).

[16] ' Tanjung S. PENGEMBANGAN MULTIMEDIA INTERAKTIF BERBASIS BUDAYA PADA MATA PELAJARAN MATEMATIKA. JURNAL TEKNOLOGI INFORMASI \& KOMUNIKASI DALAM PENDIDIKAN.;6(1):91-102.

[17] Fauziyyah FN, Juhri J. Pengembangan Multimedia Interaktif Ceria Pada Mata Pelajaran Matematika Pokok Bahasan Unsur Dan Sifat Bangun. Primary: Jurnal Keilmuan dan Kependidikan Dasar. 2017 Dec 29;9(2):311-24.

[18] Fredy F, Soenarto S. Pengembangan multimedia pembelajaran matematika pada materi bilangan bulat kelas IV SDN Lempuyangan I Yogyakarta. Jurnal Prima Edukasia. 2013 Jul 1;1(2):162-72.

[19] Hermawan H. Pengembangan Multimedia Pembelajaran Interaktif Pokok Bahasan Segitiga Dan Jajargenjang Kelas IV SD. Universitas Muhammadiyah Surakarta: Naskah Publikasi. 2016.

[20] Haryanto E. Upaya Meningkatkan Rasa Ingin Tahu Dan Prestasi Belajar Matematika Materi SifatSifat Bangun Ruang Melalui Model Pembelajaran Van Hiele Di Kelas V SD Muhammadiyah 04 Comal. Dinamika Jurnal Ilmiah Pendidikan Dasar. 2019 Jan 14;9(2).

[21] Tuningsih S, Anggoro S, Hermita N. The Reconstructing of 4th Grade Primary Students' Conception on the Concept Of Geometry using Puzzle Based Learning. InJournal of Physics: Conference Series 2020 Oct 1 (Vol. 1655, No. 1, p. 012080). IOP Publishing. 